\title{
Trauma in African women and children: a study of the Kenyan experience as
} illustration of the phenomenon

\section{FG Njenga}

President, African Association of Psychiatrists and Allied Professions, Upper Hill Medical Centre, Nairobi, Kenya

\begin{abstract}
In traditional African societies, roles and responsibilities of its members were carefully regulated, giving the community a sense of cohesion, continuity and integrity. Following the periods of colonization, wars of liberation, independence and post colonial self governments, many countries in Africa have disintegrated into volatile autocratic dictatorships that have led to many wars, genocide, internal and external displacements of the people, recently complicated by natural and man made disasters. AIDS is a recent entrant to the equation. In the midst of these changes (and traumas) the family unit has been denuded of its security, continuity and order. African traditional education systems have been replaced by ill tested western models of education, while time tested rites of passage have been declared health hazards (e.g. circumcision) in many parts of Africa. Marriage systems that traditionally conferred stability derived from the nature of the marital bonds have been replaced by fragile western monogamous unions. These changes have affected relationships "Behind Closed Doors". This paper describes the effects of this type of globalization on Africans taking Kenya as a case example, exploring domestic violence and the abuse of children.
\end{abstract}

The content of this paper was presented at a symposium "Behind closed doors in Africa. The case of women and children", American Psychiatric Association annual conference Atlanta, Georgia ,23rd May 2005. 1

Key words: Trauma, globalisation, domestic violence, women, children

Received: 22.11 .2006

Accepted: 23.01.2007

\section{Introduction}

The traditional African lifestyle gives a very specific place for women and children. In his book, "Facing Mount Kenya", Jomo Kenyatta has detailed descriptions of the life of the Gikuyu, the roles and duties of each, child and adult. ${ }^{2}$ The two chapters on Kinship and Systems of Education capture pre-colonial lifestyles in graphic detail.

The father is the supreme ruler of the homestead. He is the owner of practically everything, or in other words, he is the custodian of the family property including his wives and children. He is respected and obeyed by all the family members. His position in the community depends largely on the type of homestead he keeps, and how he manages it, because the capability of a good management of one's

\section{Correspondence:}

Frank G Njenga

P.O. Box 73749 Nairobi, Kenya, 00200

email: fnjenga@africaonline.co.ke homestead is taken as a testimonial that one is able to manage public affairs.

With the advent of the colonization of Africa, many different forces came to play leading to massive changes in the lifestyles of the people. Rural - urban migration, forced labour, entry into the cash economy, Islam, Christianity, Education are but a few of the forces that changed the human climate for children and women. In her recent book 'Unbowed'the Kenyan Nobel Laureate Wangari Maathai describes these changes in her lifetime; ${ }^{3}$

"Sadly, these beliefs and traditions have now virtually died away. They were dying even as I was born. When European missionaries came to the central highlands at the end of the nineteenth century, they taught the local people that God did not dwell on Mount Kenya, but rather in heaven, a place above the clouds. The proper place to worship him was in church on Sundays, a concept that was unknown to Kikuyus. ( page 5/6)

The social order changed rapidly as many men left their rural homes and became weekend fathers and husbands. During the week, many lived in small shanties in close 
proximity to other men in many cities in Africa, fueling the commercial sex industry and more recently fanning the HIV/ AIDS pandemic.

Mothers and children left in rural homes had to fend for themselves, while those lucky to join the breadwinners in the cities led "abnormal" lives where fathers and their adolescent daughters together with other members of the family shared single cubicles, creating new challenges for mothers, fathers and their growing children.

In the late fifties and early sixties, with the promise of independence, Africans lived the life of hope that the triple problems of poverty, ignorance and disease would evaporate under the wise leadership of their new rulers. For most Africans, the dream of a new life remained just that - a dream.

Following the death (through sickness or assassination) of the fathers of African independence, and as African governments fell in rapid succession, the stage was set for the steady decline of Law and Order, and the wars and internal strife rapidly gave way to increasing poverty, ignorance and disease. As often happens, and as had been the case during the colonial era, it was the most vulnerable, women and children who bore the brunt of those conflicts. The latter point is well illustrated in the recently published book by Caroline Elkins on Kenya's struggle for independence. ${ }^{4}$ In addition , David Anderson's book dealing with British colonial rule in Kenya records; 5

"They carried with them ropes, which they tied around the huts to prevent the occupants from opening the doors before they set the thatch alight. As the occupants struggled to clamber through the windows to escape, they were savagely cut down. Most of those caught in the attack were women and children, but they were shown no mercy by the attackers. Pagel25/6.

\section{The Decline}

With each successive coup, a new dictatorship came into being. As a result, between the dictatorship of Idi Amin in Uganda, the failed state of Somalia, the genocide of Rwanda, the brutal wars in Sierra Leone and Liberia, one is hard pressed to choose a place they would rather have been in those years. Kenya, Angola and Nigeria soon distinguished themselves as some of the most corrupt countries in the world, rated below 2 out of 10 on the corruption index by Transparency International. On the same corruption scale, and to illustrate the difference, New Zealand, Sweden and Finland all scored 9 out of $10 .{ }^{6}$

Poverty came knocking, entered and found a semipermanent home in Africa. In Kenya, Uganda and Tanzania, $42 \%, 35 \%$ and $51 \%$ of the people lived under the poverty line according to the World Bank. As a measure of extreme poverty, the figures for those living under a dollar a day were 26\% (Kenya), unknown (Uganda) and nearly 20\% for Tanzania. In contrast, no persons in the USA or UK live below the poverty line. ${ }^{7}$

To complicate the picture further for the African woman and child, came the HIV/AIDS pandemic which has ravaged the continent with unprecedented ferocity, mainly directed at women and children. If the latter do not die of infection at birth, they have to survive being orphans of which Africa has an estimated 10 million. Wars, internal displacements, refugee status as well as poverty all seem to fuel not just the infection, but also the effects of the virus.

Of the 40 million people infected with HIV worldwide, 28 million live in sub-Sahara Africa. Additionally, while 18,000 people died of AIDS in the USA, 3 million died in Africa, where in some countries e.g. Botswana, one in three people have the virus. While Kenya has 1 million people infected, there are a similar number of AIDS orphans. Infection rates in Kenya are highest among women raising questions about the reasons for the disparity. Earlier onset of sexual activity, sexual abuse, domestic violence are other considerations in explaining the higher prevalence rates in women.

\section{Kenya as an illustrative example}

The decision to report on Kenya as an illustrative example of the violence in Africa has advantages and disadvantages. It can for example be argued that Kenya is not a typical African example in that it has not gone through violent political and military upheavals that most of Africa has been through. It can also be argued that the fact that Kenya went through a peaceful political transition in December 2002, makes it unique in the region. True as these arguments are, Kenya is nonetheless typical in many other ways, social, political and economic. A look at reported corruption indices, life expectancy, infant and maternal mortality, prevalence of HIV/ AIDS, GDP and other economic indicators, all makes Kenya a fair representative of the African landscape.

In other ways, and because of her stability, Kenya has tended to carry a disproportional load of the problems in the region. A ready example is the hosting of a large refugee population from Somalia and Sudan, as well as from her other neighbors in the last few decades. This, coupled with its own experiences of the Mau Mau war of liberalization, in the fifties, gives Kenyans a true taste of internal strife and displacement. In recent times, Kenya has experienced massive internal displacement of rural people of the Rift Valley following a period of politically instigated tribal unrest in the nineties. Though largely settled now, there is evidence of lingering traumatic effects. ${ }^{8}$ Both Njenga et $\mathrm{al}^{9}$ and Seedat et $\mathrm{al}^{10}$ have separately reported on the violence in Kenya, including a comparison between Kenyan and South African children's experience of trauma. It is with this background that Kenya was selected as the site of this report.

\section{Kenya, The Country}

Kenya lies on the equator, and borders the Indian Ocean to the east. Uganda to the west is her largest trading partner and Somalia to the east is a failed state and a source of many small arms that fuel violence, as well as a source of many refugees. To the north lies Sudan, a country with much hope following peace efforts brokered by Kenya, and also a source of refugees. Also to the North is Ethiopia a country that shares a rich history with Kenya. The Maasai of Kenya \& Tanzania to the south give these two countries a bond of friendship over the generations.

Kenya occupies 582,646 sq.kms. To understand some of the challenges of the scanty natural resources in Kenya, only $20 \%$ of the land mass is classified as medium or high potential. There is a large arid and semi arid area to the north, that now is home to the Kenyan pastoralists communities who are in constant war over land, livestock and other resources. Women and children suffer the consequences of these 
displacements. To further challenge the available resources, and fueling some cases of unrest in Kenya, is the fact that 10\% of the country (58,264 sq.km) are classified as forests, woodlands, national reserves and game parks, not available to the local people.

In addition, Kenya has a very young population mainly living off the land in the rural areas, where $78 \%$ of the people reside. There is however a rapid growth of urban population (6\% per annum) contributing to urban poverty (54\% and 53\% of rural and urban Kenyans - respectively - live in absolute poverty) and violence in the poor areas of cities. $60 \%$ of the population is below the age of 18, (and hence not in the formal labor market) and the HIV/AIDS prevalence has come from a high of $15 \%$ to the current estimate of $7 \%$. The economic burden of the pandemic has had a major impact on Kenya, and slowed economic growth with projected impact on poverty and violence. Life expectancy in some parts of Western Kenya are 37 years!

It is against this background that it was felt that the Kenyan experience could give some insight into some of the problems facing women and children on the African continent. It is also worthy of note that many of the traumas that afflict mothers have a direct expression in their children.

\section{Methods}

Information from three sources was compiled to make the presentation on the violence visited on women and children in Kenya as an illustration of violence in an African country. ${ }^{10}$ It has been adapted for publication in this issue. The three sources were: the local press, a women's hospital in Nairobi, and a community survey carried out by the local chapter of a women's legal organization. Additional information was compiled from the published data from the same organization.

\section{Materials}

\section{The Local Press}

To enable the author to present prospective and at the same time current data for the conference ${ }^{10}$, the decision was made to collect data from the local print media in the week May 3rd 2005 to May 10th 2005. This was two weeks before the conference. On a daily basis, the author went through the two leading dailies in Kenya (Nation and Standard), and systematically looked for stories that suggested violence directed specifically at women or children. The idea was simply to establish the number of cases reported in the local press which was understandably not an accurate reflection of all such incidents. At an average of approximately two per day, 13 reports were noted. The headlines for the cases are reproduced below:

Man kills step-sister who was born out of wedlock; Boys, too, in danger of being abused; Agony of girl burned for eating grandma's supper; When a mother brutally turned against her child; UNICEF makes food appeal; Girl's remains are retrieved; 27-year-old rapist jailed for life; Man who killed wife loses appeal; Offers of love for baby found by dog; Woman denies strangling employer's two children; How dog rescued Baby Angel; Baby in hospital after rape; Victims of rape may have to foot bills.

These reports illustrated that women and children are the objects of violence in Kenya as reported by the local press. This method of data collection was intended to demonstrate that the problem does indeed exist in Kenya, and also that the information is available to the Kenyan public. There was no attempt to present these findings as in any way reflecting the actual numbers of women and children abused, but only to illustrate the presence of the problem.

\section{Community Monitoring}

The second part of the study involved a review of published data, derived from the work of the Kenyan chapter of the Federation of Women Lawyers. This organization has a system of collecting data from different parts of the country (Nairobi, Nyanza, Coast and Western Kenya) on the abuse of women at the community level as well as a centre for abused women at their Nairobi offices. Trained data collectors routinely compile data on cases of abuse in these selected areas. Legal advice is also available free of charge from volunteer lawyers. There are thousands of women visiting the centres each year.

From this source, we were able to establish that: $70 \%$ of the abused women were aged 20-35 years, had seven or less years of education, and on average had more than five children. No part of the city of Nairobi was spared of violence though the poorer areas had greater representation in this sample.It was further noted that sometimes abuse starts in the first year of marriage, but it takes five years for most of the women to visit the shelter for help. The police, church, community elders as well as the local administration were the choice of place for the reports of the violence.

With regard to associations, it was found that alcohol abuse, low self esteem in men, adultery and the fact that some women seemed to be doing better than their male partners contributed to the violence in different ways.Husbands, fathers, brothers as well as neighbors and other male relatives were all cited as perpetrators of the violence.

The consequences of the violence were reported as follows: scars and bruises - 43\%, fractures - 6\%, loss of hair $7.6 \%$, death $-1.3 \%$ and injuries requiring hospitalization $22.8 \%$. Other consequences of the violence included sexually transmitted diseases $-24 \%$, unwanted pregnancy - 16\%, miscarriage $-4 \%$. Most of the violence took place at home $77 \%$, with $8 \%$ in public places, work $5 \%$ and $7 \%$ taking place in other places. $28 \%$ of the women visited the centre after the first act of violence, 30\% after beatings that occurred at least once a week and $20 \%$ after violence of a frequency of about once a month.

The violence was most frequently reported to the authorities by the survivors - 60\%, a family member - $20 \%$, The Federation of Women Lawyers, Kenya (FIDA) monitors -7\% as well as neighbors 5\% and friends 1\%. Only 15\% of the survivors reported the violence immediately, 37\% waited at least one week, 10\% did not report the matter for various reasons, including fear of repercussions $-32 \%$, not knowing what to do- $22 \%$, while others were so injured that they were unable to report. $2 \%$ of the women thought nobody would believe their story.

Asked why they continue to suffer in the hands of men, $36 \%$ said it was for the sake of the children, 32\% hoped the violence would end, $15 \%$ felt they needed to stay for economic reasons while 8\% did so for what they called reasons of culture.

Asked why they stayed so long without doing anything, the survivors said they hoped he would change in time, while others 
said it was against their faith to break up a marriage while others stayed "with the devil they know", while others felt too old to start all over again. Others blamed themselves saying they were perhaps not good enough for the men, while others felt they did not show enough love to their men and hence the violence.

\section{Hospital Data}

The third source of information was a local women's hospital, Nairobi Women's Hospital which runs a Gender Based Violence (GBV) Centre. Data for the 3 years, 2002, 2003, 2004 are presented in Tables I, II and III respectively.

Each of the three tables represent somewhat different data, but taken together illustrate the point of the steady increase in the numbers seen, thus illustrating the basis of concern.

\begin{tabular}{|l|l|l|l|}
\hline \multicolumn{4}{|c|}{ Table I: Summary of clients attended to - 2002} \\
\hline & $\begin{array}{l}\text { Actual No. of } \\
\text { clients attended to }\end{array}$ & $\begin{array}{l}\text { No. of domestic } \\
\text { violence cases }\end{array}$ & No. of rape cases \\
\hline $\begin{array}{l}\text { Women } \\
\begin{array}{l}\text { Men } \\
\text { Children }\end{array}\end{array}$ & $\begin{array}{l}330 \\
2\end{array}$ & 106 & 224 \\
\hline Total & 13 & 1 & 1 \\
\hline
\end{tabular}

Table II Proportion of Survivors of Gender Based Violence Reporting to the centre -2003

\begin{tabular}{|l|l|l|}
\hline & No. & $\%$ \\
\hline Attempted Rape & 22 & 2 \\
Domestic Violence & 284 & 27 \\
Rape & 447 & 43 \\
Defilement & 293 & 28 \\
\hline Total & $\mathbf{1 0 4 6}$ & $\mathbf{1 0 0}$ \\
\hline
\end{tabular}

Table III Cases of GBV by nature of assault -2004

\begin{tabular}{|l|l|l|}
\hline & No. & $\%$ \\
\hline Rape & 824 & 47 \\
Defilement & 659 & 38 \\
Domestic & 273 & 15 \\
\hline Total & $\mathbf{1 7 5 6}$ & $\mathbf{1 0 0}$ \\
\hline
\end{tabular}

The steady increase in the numbers seen is self evident in 2002 , (345), 2003,(1046) and 2004, (1756) with many cases of rape, defilement and other forms of domestic violence.

\section{Discussion}

Taken together, these three sources of information support the author's opinion that violence against women and children occurs in Kenya in numbers sufficient to cause concern, and to demand intervention by the scientific community. The three sources of information, when taken together argue for the need to carry a more vigorous study of the phenomenon. The survey carried out by FIDA, the newspaper review as well as the visits to the women's hospital are, taken together reliable indicators of the existence of the phenomenon. They are however not reliable indicators of the extent of the problem. In this regard, this study is limited in a manner that can only be covered by either a population based cross-sectional study, or a prospective community based study. This study therefore serves to underscore the existence of a problem in Kenya without attempting to quantify its magnitude. A number of experts have in the past attempted to quantify the problem as well as attempt to explain its possible causes. Whereas the extent of the problem can be qualified, by well designed studies, and whereas legislation can go some way in dealing with the problems, its cause or causes must rely on more gradual societal changes at a number of levels including respect of individual physical and emotional integrity, a sense of community as well as respect for human rights. Education in all these areas must remain a key factor, that is carried out by governments, civil society as well as non-governmental organizations, dealing with gender equality. Matters of equality in society must be brought to the discussion table.

The traditional African lifestyle gives a very specific place for women and children With the advent of the colonization of Africa, many different forces came to play leading to massive changes in the lifestyles of the people. It was felt that the Kenyan experience could give some insight into some of the problems facing women and children on the African continent. Information from three sources was compiled: the local press, a women's hospital in Nairobi, and a community survey carried out by the local chapter of a women's legal organization.

\section{Conclusion}

This paper has demonstrated, through a review of the Kenyan experience, the violent nature of an African society as well as the serious nature of the problem. It is here suggested that poverty reduction as well as legislation such as a Children's Act, Domestic violence Act and a Sexual offences Act may be some ways of addressing the traumas experienced by African women and children. Public education, and other measures of achieving attitudinal change as well as police training might be useful additional ways of addressing the problem.

There is however no doubt that the issues are more complex than this and that search for a lasting sustainable solution will have to be preceded by systematic scientific study of the very many and varied causes of these problems.

\section{References}

1. Njenga FG. Behind closed doors in Africa. The case of women and children. Paper presented at the American Psychiatric Association annual conference, Atlanta, Georgia, USA, 23rd May 2005.

2. Kenyatta J. Facing Mount Kenya: The Traditional Life of the Gikuyu. Kenway Publications, 1995

3. Mathai WM. Unbowed: A Memoir. William Heinemann, 2006.

4. Elkins C. Britain's Gulag: The Brutal End of Empire in Kenya. Pimlico, 2005.

5. Anderson D. Histories of the Hanged: Britain's Dirty War in Kenya and the End of Empire. Phoenix Publishers, 2006.

6. Transparency International website www.transparency.org

7. World Development Report Building Institutions for Markets. The World Bank, 2002.

8. Njau JW. Post-Traumatic Stress Disorder Among the Heads of Households of Ethnic Clashes Survivors in the Rift Valley Province, Kenya: A Comparative Study. MMed Psychiatry Thesis, University of Nairobi, Kenya, 2005

9. Seedat S, Nyamai C, Njenga F, Vythilingum B, Stein DJ. Trauma Exposure and Posttraumatic Stress Symptoms in Adolescents: A Schools' Survey in Cape Town (South Africa) and Nairobi (Kenya). British Journal of Psychiatry 2004; 184: 169 - 175.

10. Njenga F G, Nyamai, C N, Kigamwa P A, Davidson J, Nichols, P J. Post-traumatic stress after terrorist attack: psychological reactions following the US embassy bombing in Nairobi: Naturalistic study. British Journal of Psychiatry 2004; 185: 328 - 333. 